\title{
Proximate Composition and Micronutrient Contents of Callianassa turnerana from the Wouri Estuary, Cameroon
}

Jean Michel Njinkoué ${ }^{1}$, Rodrigue Foumedzo ${ }^{1}$, Marlyse Solange Leng ${ }^{1}$, Justin Djimbie Djopnang ${ }^{2}$, Adélaïde Démassé Mawamba ${ }^{1}$, Marie Modestine Kana ${ }^{1}$, Florian J. Schweigert ${ }^{3}$, Inocent Gouado ${ }^{1} \&$ François $^{2}$ Tchoumbougnang ${ }^{2}$

${ }^{1}$ Laboratory of Foods Sciences and Nutrition, Faculty of Sciences, University of Douala, Po Box 24157 Douala, Cameroon

${ }^{2}$ Laboratory of Fisheries \& Aquatic resources, Institute of Fisheries \& Aquatic Sciences at Yabassi, University of Douala, Po Box 7236 Douala, Cameroon

${ }^{3}$ Department of physiology and pathophysiology of Nutrition, University of Potsdam, Universität Potsdam, Postfach $601553 \cdot 14415$ Potsdam, Germany

Correspondence: Jean Michel Njinkoué, Laboratory of Foods Sciences and Nutrition, Faculty of Sciences, University of Douala, Po Box 24157 Douala, Cameroon. Tel: 0023-7699-912197/0023-767-885-7198. E-mail: jmnjinkoue@yahoo.fr

ORCID: 0000-0003-4953-5885

Received: October 1, 2018

Accepted: October 19, 2018

Online Published: December 28, 2018

doi:10.5539/jfr.v8n1p32

URL: https://doi.org/10.5539/jfr.v8n1p32

\begin{abstract}
Callianassa turnerana, called Cameroon ghost shrimps is shrimp with a great sociocultural interest in Cameroon. This study assessed proximate composition and micronutrients contents of Callianassa turnerana from the Wouri estuary in Cameroon. Adult shrimps were collected. The proximate composition, mineral, carotenoids and vitamin $\mathrm{E}$ contents were determined in edible parts (male and female) and in eggs of $C$. turnerana using official analytical methods. One way ANOVA and Fisher's post hoc PLS test was used to analyze the data. The moisture content were $66 \pm 1.5 \%, 62 \pm 2.85 \%, 49.0 \pm 1.60 \%$ in edible parts of male, female and in eggs respectively. Protein contents were high in all the samples ranging from $10.49 \pm 0.92 \%$ in male edible parts to $30.06 \pm 0.89 \%$ in eggs. Lipid contents were more than $12 \%$ in all samples. Carbohydrate were absent in eggs while the contents were $9.92 \pm 0.99 \%$ in male and $12.23 \pm 0.81 \%$ in female edible parts. $C$. turnerana is a good source of minerals. Sodium $(0.983 \pm 0.001 \%-1.656 \pm 0.005 \%)$ and Phosphorus $(0.974 \pm 0.002 \%-1.321 \pm 0.002 \%)$ were the main macro elements in all samples. $\mathrm{Zn}$ was the major microelement in edible parts with the value ranged from $6.43 \pm 0.49 \mathrm{mg} / 100 \mathrm{~g}$ (male) to $7.62 \pm 0.35 \mathrm{mg} / 100 \mathrm{~g}$ (female) while $\mathrm{Cu}$ was the major microelement $(10.15 \pm 3.57 \mathrm{mg} / 100 \mathrm{~g}$ ) in eggs. High levels of total carotenoids $(7.9-15.45 \mu \mathrm{g} / \mathrm{g})$ and vitamin $\mathrm{E}(12.53-24.03 \mu \mathrm{g} / \mathrm{g})$ were recorded. The main carotenoids were $\beta$-caroten $(0.637-1.337 \mu \mathrm{g} / \mathrm{g})$ followed by $\alpha$-caroten $(0.216-0.437 \mu \mathrm{g} / \mathrm{g})$. C. turnerana is a good source of many major nutrients and micronutrients and could be used to combat malnutrition and improve health.
\end{abstract}

Keywords: Callianassa turnerana, proximate composition, micronutrients, Wouri estuary, Cameroon

\section{Introduction}

Shellfish is worldwide known for its nutritional and economic interest. As the most consumed shellfish, shrimps hold an important place in fishing activities (Food and Agricultural Organisation [FAO], 2016). The increasing demand in shrimps is justified by their nutritional values and their shells. In fact, they are rich in proteins, carotenoids (astaxanthin), polyunsaturated fatty acids $\omega 3$ and $\omega 6$, minerals, chitin, low in lipids, calories and saturated fat (Ravichandran, Rameshkumar \& Rosario, 2009; Maniadis-Meimaroglou \& Sinanoglou, 2012). Because of theirs high nutritional value and properties, shrimps are used as food for human an animal, as neutraceutic in pharmaceutical and cosmetics industries. They provide proteins of high biological quality and essential amino acids (Yanar \& Celik, 2006; Sriket et al., 2007). In Cameroon, C. turnerana commonly called ghost shrimp and localy "mbéatoé or mbotoré" is collected in the littoral region, and especially in the Wouri river estuary where a swarming happens once a year during heavy rainfall (July and August) within 2 or 3 days only. This shrimp is very special to Cameroon as from it, comes the name of the country. Portuguese, in the 15th 
century discovered the Cameroon River. They arrived at the time when C. turnerana was swarming. Greatly impressed by this phenomenon, they named the river "Rio dos camaraos" which mean Shrimps River. The English translated this to "Cameroon River", and the name Cameroon was used for the country and also adopted in other languages (Cameroun in French, Kamerun in Germany...) (Holthuis, 1991). The swarming of $C$. turnerana is the sign for the native population for large scale fishing activities. Local populations enjoy eating $C$. turnerana. They consumed it fresh or smoked. They are also used it as treatment of many diseases. In Cameroon, some biological studies have been reported on this shrimp (Holthuis, 1991); however, no data are available regarding chemical composition of $C$. turnerana. This nutritional study is the first on this shrimp specie in Cameroon. The objective of this study was to evaluate the nutritional composition of $C$. turnerana of the Wouri estuary in Cameroon. Specifically, it aims at determining proximate composition, carotenoids profile, mineral and vitamin E contents.

\section{Materials and Methods}

\subsection{Biological Material Collection}

Callianassa turnerana was obtained early in the morning from the artisanal fishermen at the Wouri river estuary in august 2017. Shrimp were introduced in an icebox under cooled conditions and transported to the Laboratory of Foods Sciences and Nutrition at the Faculty of Sciences of the University of Douala. Collected samples were screened, washed with deionized water to remove all adhering contaminations. The length of the shrimp was measured using an ichtiometer and their weight was obtained using a scale.

\subsection{Sample Preparation}

Males were separated from females. Eggs in the female's body forming an orange stripe running from cephalothorax to the first two abdominal segments were carefully removed. Edible parts made up of flesh, abdominal adipose tissue, exoskeleton hypocalcified of males and females were obtained after removal of their crowbars as well as heads which would contain a throat irritant substance.

\subsection{Proximate Analysis}

Moisture content was determined using the hot air oven, by drying the sample at $105^{\circ} \mathrm{C} \pm 2^{\circ} \mathrm{C}$ until a constant weight was obtained (Association of Official Analytical Chemists [AOAC], 2005). Total lipids were determined by Bligh and Dyer method using chloroform/methanol (1/1, v/v) (Bligh \& Dyer, 1959). Crude protein contents were evaluated by Kjeldahl's method (Nx6.25) (AOAC, 1984; Anderson \& Ingram, 1993; Buondonno, Rashad, \& Coppola, 1995); Ashes contents were determined after combustion for $20 \mathrm{~h}$ at $550^{\circ} \mathrm{C}$ (AOAC, 2005). Total carbohydrate contents were determined by subtracting the sum of fat, proteins, ash and moisture contents from $100 \mathrm{~g}$ of shrimp (Onyeike, Ayoologu, \& Ibegbulam, 2000). All analysis were carried out in triplicate.

\subsection{Mineral Analysis}

Minerals $\mathrm{Ca}, \mathrm{Na}, \mathrm{K}, \mathrm{P}$, and $\mathrm{Mg}$, as macroelements and $\mathrm{Fe}, \mathrm{Cu}, \mathrm{Mn}, \mathrm{Zn}$ as trace minerals were determined in the edible parts and eggs of the shrimps after ashing. Prior to these analysis, ash was weighted, mineralized into nitric acid $\left(\mathrm{HNO}_{3}\right), \mathrm{HClO}_{4}$ and deionised water (Pauwels et al., 1992). Mineral contents of the solubilised samples were determined by flame atomic absorption spectrophotometry, using a BUCK Scientific 200A apparatus for $\mathrm{Ca}, \mathrm{Na}, \mathrm{K}, \mathrm{Mg}, \mathrm{Fe}, \mathrm{Zn}, \mathrm{Cu}, \mathrm{Mn}$ (Benton \& Case, 1990; Anderson \& Ingram, 1993). Phosphorus was analyzed by colorimetry method using a UV spectrophotometer (Murphy \& Riley, 1962).

\subsection{Total Carotenoïd Content}

Total carotenoids contents were determined by the method described by Simpson, Tisou \& Chichester, 1987. Three grams (3g) of fresh shrimps were pounded and introduced in $10 \mathrm{ml}$ of hexan/ethanol $(1 / 1 ; \mathrm{v} / \mathrm{v})$. The whole mixture was shacked strongly and kept in darkness for 15 hours at $4^{\circ} \mathrm{C}$. Total carotenoids were determined by a photometer (ichek ${ }^{\mathrm{TM}}$ Carotene ; BioAnalyt GmbH, Teltow, Germany).

\subsection{Determination of Carotenoids Profile and Vitamin E}

\subsubsection{Sample Preparation}

About $0.5 \mathrm{~g}$ of crushed sample was introduced in a polypropylene tube. One milliliter of distilled water was then added to the tube. The mixture was shacked and allowed to stand for $30 \mathrm{~min}$. Carotenoids and vitamin $\mathrm{E}$ extraction was carried out in a mixture of hexane-isopropanol (3: 2, v / v) under stirring (15 min) using a programmable Rotator Mixer RM-Multi 1. The mixture was then subjected to centrifugation at $3800 \mathrm{tr} / \mathrm{min}$ for 5 min using a Thermo Scientific Heraeus Labofuge 200 centrifuge. This operation was repeated twice. After centrifugation, sodium chloride $(0.1 \mathrm{M})(5 \mathrm{ml})$ was added to the supernatant. The solution was stirred and allowed to stand for $30 \mathrm{~min} .7 .5 \mathrm{ml}$ of hexane containing $0.005 \%$ BHT was then added; the mixture shacked and 
the supernatant collected in a new tube. This last operation was repeated in $5 \mathrm{ml}$ of hexane containing $0.005 \%$ BHT. The supernatants were collected and the volume adjusted to $20 \mathrm{ml}$ with hexane. $200 \mu \mathrm{l}$ of supernatant was transferred in a clean polyethylene tube. The solution was then concentrated in a Techne sample concentrator, SBHCONC/1 under nitrogen (10-15 min). The residue was dissolved in $200 \mu \mathrm{l}$ of isopropanol and ultrasonicated for 5 minutes. The liquid was then centrifuged at $5000 \mathrm{rpm}$ for 5 minutes. The supernatant was placed in HPLC vial and ready to be injected into the column.

\subsubsection{Instrumentation}

The chromatography was carried out using a Shimadzu system (Columbia, MD) composed of CBM-20A System Controller, two LC-10ADvp pumps, SIL 10ADvp Auto sampler injector, CTO-10ASvp column oven, and SPD-20A photodiode array detection system set in a range of $100-500 \mathrm{~nm}$ (all from Waters, Milford, MA, USA). Vitamin E and carotenoids were separated on a reversed C18 column $(250 \times 3 \mathrm{~mm}$ I.D.; particle size, 5 $\mathrm{mm}$ ) from Merck KGaA (Darmstadt, Germany). The chromatography was carried out using a step gradient elution mode in which eluent A was a mixture of Methanol- Ammonium acetate (water solution) (90: $10 \mathrm{v} / \mathrm{v})$ and eluent B, the mixture of Methanol-Ammonium acetate-terButhyl methyl ether (8: 2: 90, v/v/v) at a flow-rate of $0.2 \mathrm{ml} / \mathrm{min}$.

\subsubsection{Quantification}

Peaks were identified by their retention time and absorption spectra were compared to those of known standards (Sigma Chemicals). Carotenoids and vitamin E were quantified using peak areas of the authentic standard.

\subsection{Statistical Analysis}

All results are expressed as the mean of three measurements. Data were presented as mean \pm standard deviation. One way ANOVA was performed to test the differences in nutrient contents between the different parts of shrimp. Fisher's post hoc PLSD test was used as classification test. Significance was established at P $<0.05$. Statistical analyses were done using SPSS 16.0 for windows (SPSS, Chicago, IL, USA).

\section{Results}

The average weight and length of Callianassa turnerana were $41.5 \pm 6.513 \mathrm{~g}$ and $22.5 \pm 1.007 \mathrm{~cm}$ respectively for males. The values recorded for the females shrimp were $29.0 \pm 6.131 \mathrm{~g}$ for weight and $19.5 \pm 1.691 \mathrm{~cm}$ for length. Eggs stand for $15.84 \pm 3.74 \%$ of the female's edible part.

\subsection{Proximal Composition}

Table 1 shows the proximal composition of the edible parts of males, females and eggs of $C$. Turnerana.

Table 1. Proximal composition of the edible part of male, female and eggs of $C$. Turnerana

\begin{tabular}{llll}
\hline & Male & Female & Eggs \\
\hline Moisture (\%) & $66 \pm 1.50^{\mathrm{a}}$ & $62 \pm 2.85^{\mathrm{b}}$ & $49 \pm 1.60^{\mathrm{c}}$ \\
Lipids (\%) & $13.02 \pm 0.55^{\mathrm{a}}$ & $12.33 \pm 0.14^{\mathrm{a}}$ & $20.36 \pm 2.82^{\mathrm{b}}$ \\
Proteins (\%) & $10.49 \pm 0.92^{\mathrm{a}}$ & $12.88 \pm 1.4^{\mathrm{b}}$ & $30.06 \pm 0.89^{\mathrm{c}}$ \\
Ash (\%) & $0.57 \pm 0.07^{\mathrm{a}}$ & $0.55 \pm 0.10^{\mathrm{b}}$ & $0.58 \pm 0.30^{\mathrm{a}}$ \\
Carbohydrates (\%) & $9.92 \pm 0.99^{\mathrm{a}}$ & $12.23 \pm 0.81^{\mathrm{b}}$ & 0.00 \\
\hline
\end{tabular}

Values are means \pm standard deviation for three analyses. In the same line, values with different letters are significantly different at $\mathrm{p}<0.05$.

As shown in table 1, chemical composition (moisture, lipids, proteins, carbohydrates and ashes) of the shrimp varied with sex and tissue (edible part or eggs). The water contents were lower than $70 \%$ and were significantly different between the edible parts of male, female and eggs $(\mathrm{p}<0.05)$. The male edible part has the highest value $(66 \%)$ and eggs the lowest $(49 \%)$. Ash $(0.58 \pm 0.3 \%)$, protein $(30.06 \pm 0.89 \%)$, and lipids $(20.36 \pm 2.82 \%)$ contents were significantly $(\mathrm{p}<0.05)$ higher in eggs than in the edible parts of male $(0.57 \pm 0.07 \%, 10.49 \pm 0.92 \%$, $13.02 \pm 0.55 \%$ respectively) and female $(0.55 \pm 0.1 \%, 12.88 \pm 1.4 \%, 12.33 \pm 0.14 \%$ respectively). Ash contents were less than $1 \%$ in all samples. A significant difference was only observed between protein and carbohydrate values of female and male edible parts. Elsewhere, carbohydrate were absent in eggs but found with high contents in edible part of males and females.

\subsection{Mineral contents}

Mineral composition ( $\mathrm{P}, \mathrm{Na}, \mathrm{K}, \mathrm{Ca}, \mathrm{Mg}, \mathrm{Zn}, \mathrm{Cu}, \mathrm{Fe}, \mathrm{Mn}$ ) of eggs and edible part (males and females) of $C$. turnerana are given in table 2 . 
Table 2. Macro and microelements contents in the edible parts of male, female and eggs of $C$. turnerana

\begin{tabular}{llll}
\hline Mineral & Male & Female & eggs \\
\hline $\mathrm{Ca}(\%)$ & $0.131 \pm 0.002^{\mathrm{a}}$ & $0.111 \pm 0.00^{\mathrm{b}}$ & $0.422 \pm 0.003^{\mathrm{c}}$ \\
$\mathrm{Mg}(\%)$ & $0.205 \pm 0.00^{\mathrm{a}}$ & $0.198 \pm 0.004^{\mathrm{a}} 0.291 \pm 0.00^{\mathrm{a}}$ & $0.17 \pm 0.003^{\mathrm{b}}$ \\
$\mathrm{K}(\%)$ & $0.291 \pm 0.00^{\mathrm{a}}$ & $0.968 \pm 0.001^{\mathrm{a}}$ & $0,470 \pm 0.001^{\mathrm{b}}$ \\
$\mathrm{P}(\%)$ & $0.974 \pm 0.002^{\mathrm{a}}$ & $0.984 \pm 0.00^{\mathrm{a}}$ & $1.321 \pm 0.002^{\mathrm{b}}$ \\
$\mathrm{Na}(\%)$ & $0.983 \pm 0.001^{\mathrm{a}}$ & $3.38 \pm 0.00$ & $1.656 \pm 0.005^{\mathrm{b}}$ \\
$\mathrm{Na} / \mathrm{K}$ ratio & $3.37 \pm 0.007$ & $0.115 \pm 0.00$ & $3.54 \pm 0.03$ \\
$\mathrm{Ca} / \mathrm{P} \mathrm{ratio}$ & $0.135 \pm 0.001$ & $7.62 \pm 0.35^{\mathrm{b}}$ & $0.32 \pm 0.002$ \\
$\mathrm{Zn}(\mathrm{mg} / 100 \mathrm{~g})$ & $6.43 \pm 0.49^{\mathrm{a}}$ & $4.05 \pm 1.12^{\mathrm{a}}$ & $3.62 \pm 1.03^{\mathrm{c}}$ \\
$\mathrm{Cu}(\mathrm{mg} / 100 \mathrm{~g})$ & $3.36 \pm 0.35^{\mathrm{a}}$ & $0.63 \pm 0.21^{\mathrm{b}}$ & $10.15 \pm 3.57^{\mathrm{b}}$ \\
$\mathrm{Mn}(\mathrm{mg} / 100 \mathrm{~g})$ & $0.53 \pm 0.02^{\mathrm{a}}$ & $6.51 \pm 2.75^{\mathrm{b}}$ & $0.92 \pm 0.07^{\mathrm{c}}$ \\
$\mathrm{Fe}(\mathrm{mg} / 100 \mathrm{~g})$ & $7.60 \pm 0.49^{\mathrm{a}}$ & & $6.29 \pm 2.96^{\mathrm{b}}$ \\
\hline
\end{tabular}

Values are means \pm standard deviation for tow analyses. In the same line, values with different letters are significantly different at $\mathrm{p}<0.05$.

Sodium and phosphorus were the most abundant macroelements $C$. turnerana. These minerals were significantly higher in eggs than in edible part (male or female). Eggs has significant highest value in $\mathrm{Ca}(0.422 \pm 0.003 \mathrm{~g} / 100 \mathrm{~g})$, $\mathrm{K}(0.470 \pm 0.001 \mathrm{~g} / 100 \mathrm{~g}), \mathrm{Cu}(10.15 \pm 3.57 \mathrm{mg} / 100 \mathrm{~g})$ and $\mathrm{Mn}(0.92 \pm 0.07 \mathrm{mg} / 100 \mathrm{~g})$. Edible part stands with a significant highest value in iron $(7.6 \pm 0.49 \mathrm{mg} / 100 \mathrm{~g})$ in male and zinc $(7.62 \pm 0.35 \mathrm{mg} / 100 \mathrm{~g})$ in female. Male edible part has significant higher value in calcium than female part which has the highest value in magnesium in comparison. $\mathrm{Ca} / \mathrm{P}$ ratio were less than 1 in all samples while $\mathrm{Na} / \mathrm{K}$ is about 3.50 .

\subsection{Contents of Total Carotenoids, Vitamin E and Carotenoids Profile}

Total contents of carotenoids, vitamin $\mathrm{E}$ and carotenoids profiles of $C$. turnerana are shown in table 3.

Table 3. Contents of total carotenoids, vitamin $\mathrm{E}$ and carotenoids profiles of $C$. turnerana $(\mu \mathrm{g} / \mathrm{g})$

\begin{tabular}{llllllll}
\hline Samples & total Carotenoids & $\alpha$-tocopherol (Vit E) & Astaxanthin & Lutéin & $\alpha$-caroten & $\beta$-caroten & Lycopen \\
\hline Males & $7.91 \pm 0.09^{\mathrm{a}}$ & 13.79 & 0.051 & 0 & 0.216 & 0.637 & 0 \\
Females & $8.68 \pm 0.22^{\mathrm{a}}$ & 12.53 & 0.035 & 0 & 0.409 & 1.116 & 0.009 \\
Eggs & $15.45 \pm 1.93^{\mathrm{b}}$ & 24.03 & 0.042 & 0.005 & 0.437 & 1.337 & 0.005 \\
\hline
\end{tabular}

The values presented for total carotenoids are averages and their standard deviation $(X, \sigma),(\mathrm{n} 3)$, and in the same column, values carrying the different letters are significantly different with (p 0,05$)$.

Eggs has significant highest contents in total carotenoids $(15.48 \pm 1.9 \mu \mathrm{g} / \mathrm{g})$, vitamin E: alpha-tocopherol $(24.03 \mu \mathrm{g} / \mathrm{g})$, alpha- carotene $(0.437 \mu \mathrm{g} / \mathrm{g})$ and beta-carotene $(1.337 \mu \mathrm{g} / \mathrm{g})$. Beta-carotene $(0.637,1.116$ and $1.337 \mu \mathrm{g} / \mathrm{g}$ in males, female and eggs respectively) was the most abundant carotenoid followed by alpha-carotene $(0.216,0.409$ and $0.437 \mu \mathrm{g} / \mathrm{g}$ respectively) and astaxanthine $(0.051,0.035$ and $0.042 \mu \mathrm{g} / \mathrm{g}$ respectively). Lycopen was not found in males in contrary of females and eggs. Eggs were found with little levels of lutein $(0.005 \mathrm{~g} / \mathrm{g})$ which in turn was absent in males and females edible parts. Zeaxanthin and beta-cryptoxanthin were not found in C. turnerana.

\section{Discussion}

Average weight and length of $C$. Turnerana found are above those usually consumed by local populations. This shows that shrimps used in this study were adults. The length of adult $C$. turnerana normally varied from $5.5 \pm 2.2$ to $14.5 \pm 5.7 \mathrm{~cm}$ (Holthuis, 1991).

\subsection{Proximal Composition}

The level of moisture recorded in this study was lower than the range value (75-80\%) reported in previous works in other shrimps (Ekpenyong, Williams \& Osakpa, 2013; Dincer, \& Ayidin, 2014).

Protein contents of $C$. turnerana were lower than those of Penaeus semislcatus from Arabian Gulf described by Musaiger \& D'Souza Musaiger (2008), and in flesh of M. macrobranchiun (Ekpenyong et al., 2013). However they were higher than those of Penaeus monodon (9.21\%) and P. notialis (6.09\%) (Bernard \& Yewande-Bolatio, 2016). These high values of proteins indicated that $C$. turnerana is a good source of proteins. With fat content more than $10 \%$, C. turnerana belongs to the fat species class of shellfish. Ash contents were lower than those 
found in P. monodon (3.53 $\pm 0.06 \%)$, P. notialis $(4.89 \pm 0.03 \%)$ (Bernard \& Yewande-Bolatio, 2016; Oksuz et al., 2009) and in of Metapenaeus affinis (1.1\% and $1.86 \pm 0.08 \%$ for male and female respectively)(Dincer, \& Ayidin, 2014). Carbohydrate values found in C. turnerana edible parts were higher when compared to the other shrimp's species (Dincer, \& Ayidin, 2014). High level of carbohydrate found in males and females' edible parts could be explained by occurrence of low calcified shell rich in chitin and by the glycogen stored in muscle, responsible for their sweet taste. This high level of carbohydrate indicates that as stated by Varadharajan \& Soundarapandian (2014) fat were not the only energy stock in shrimps, but also carbohydrate. Similar reports were found in $P$. monodon and P. notialis from Nigeria (Bernard \& Yewande-Bolatio, 2016).

\subsection{Mineral Contents}

\subsubsection{Macroelements (Na, K, P, Ca, Mg)}

Sodium was the most abundant element of $C$. turnerana. This result corroborate those reported by Ravichandran et al. (2012) in Penaeus indicus and Gunalan et al. (2013) in Litopenaeus vannamei. These authors reported high level in Na compared to potassium. This result is however contrary to work reported by Bello (2013) on Penaeus notialis where potassium levels were higher than sodium levels. Sodium and potassium play an important role in the body. Sodium is the main regulator of extracellular liquid, which maintain the acido-basic equilibrium, it activates enzymes and maintain osmotic equilibrium which is essential for the nervous system. Daily requirement of $\mathrm{Na}$ is about $1.5 \mathrm{~g}$. Potassium helps to maintain the fluid electrolytes balance and the integrity of the cells during the nervous transmission and the muscle contraction. Daily requirement of potassium is about $2 \mathrm{~g}$ (Rodwell, 1994). Higher levels of Na compared to potassium in this study increase the $\mathrm{Na} / \mathrm{K}$ ratios with values ranging between $3.37 \%$ and $3.54 \%$. This ratio is in fact, a key parameter to maintain the water equilibrium of the body, and is generally less than 1 in many foods (Bu, 2012; Perez, Ellen, \& Chang, 2014). The high Na/K ratios up than 1 recorded indicate that $C$. turnerana is very useful and well adapted for persons suffering for burns and deshydratation. The $\mathrm{Ca} / \mathrm{P}$ ratio is less than 1 ; showing that phosphorus was most abundant than calcium in $C$. turnerana. Similar results were reported by Babu et al. (2010) in Bursa spinosa, a gastropod of the indian coasts and by Ehigiator and Oterai (2012) in Macrobrachium vollenhovenii from Benin. The normal value of this $\mathrm{Ca} / \mathrm{P}$ ratio in food is approximately 1 (Belitz, Crock, \& Schieberie, 2009). Phosphorus is one of the essential components of nucleic acids and nucleoproteins implied in cellular division and transmission of hereditary features. It also acts like a key substance for the release of energy (Golub, 2011). Its daily requirement is approximately $1.2 \mathrm{~g}$. Similar results were obtained by Ehigiator and Oterai (2012) in the flesh of Macrobrachium vollenhovenii from Benin.

The magnesium contents $(0.17 \pm 0.003-0.205 \pm 0.00 \%)$ obtained are higher than those found by Adeyeye et al. (Adeyeye, Adebiora \& Awodola, 2008) $(0.021 \mathrm{~g} / 100 \mathrm{~g})$ in the pink shrimp, Penaeus notialis from Nigeria and by Ehigiator and Oterai (2012) in the flesh of Macrobrachium vollenhovenii from Benin (0.020g/100g). Magnesium is necessary for the enzymatic system of the body. It has a major role for the synthesis of proteins of marrowy tissue and takes part in the energy metabolism. The daily needs are approximately of $0.35 \mathrm{~g}$ (Rodwell, 1994).

\subsubsection{Microelements (Fe, $\mathrm{Zn}, \mathrm{Cu}$, and $\mathrm{Mn}$ )}

Iron contents of $C$. turnerana $(6.29 \pm 2.96-7.60 \pm 0.49 \mathrm{mg} / 100 \mathrm{~g})$ were higher than those found by Abdullah et al. (2009) in the pink shrimp Parapenaeus longirostris $(1.8 \mathrm{mg} / \mathrm{g}$ ) and in red Parapenaeus martia $(0.2 \mathrm{mg} / 100 \mathrm{~g})$ from Turkey. However, these contents were lower than those found by Adeyeye et al. (2008) in the pink shrimp Panaeus notialis $(16.6 \mathrm{mg} / 100 \mathrm{~g})$ from Nigeria and by Bernard and Yewande-Bolatio (2016) in Penaeus notialis $(28.05 \mathrm{mg} / 100 \mathrm{~g})$ and Penaeus monodon $(41.25 \mathrm{mg} / 100 \mathrm{~g})$ from the South-west of the same country. Iron $(\mathrm{Fe})$ is used for oxygen transport, necessary to the energy production in cells, particular in muscular cells and is essential to the formation of the red blood cells, and synthesis of hormones and neurotransmettors (Camara et al., 205). The daily requirements out of iron are 1 to $3 \mathrm{mg} /$ day (Rodwell, 1994). Zinc contents of $C$. turnerana $(3.62 \pm 1.03-7.62 \pm 0.35 \mathrm{mg} / 100 \mathrm{~g})$ were higher than those found by Sriket et al. (2007) in Panaeus monodon $(1.73 \mathrm{mg} / 100 \mathrm{~g})$ and Litopanaeus vannamei $(1.47 \mathrm{mg} / 100 \mathrm{~g})$ from Thaïland and by Ehigiator and Oterai (2012) in Macrobrachium vollenhovenii's flesh $(1.16 \pm 0.06 \mathrm{mg} / 100 \mathrm{~g})$ from Benin. These important values show that $C$. turnerana is a good source of zinc. This mineral is found in all body tissue and is component of more than 300 enzymes where it acts as cofactor. It takes part in immune reactions, synthesis of the genetic material, perception of the taste, healing of wounds and in foetal development. The daily requirements of zinc are of 8 to $10 \mathrm{mg}$ (Bender, 1992). High content of copper in the eggs $(10.15 \pm 3.57 \mathrm{mg} / 100 \mathrm{~g})$ and in the edible parts of the males $(3.36 \pm 0.35 \mathrm{mg} / 100 \mathrm{~g})$ and females $(4.05 \pm 1.12 \mathrm{mg} / 100 \mathrm{~g})$ show that $C$ turnerana is a good source of copper. These contents found in the edible part of the males and females are similar to those reported by Bernard and Yewande-Bolatio (2016) in Penaeus notialis $(3.7 \mathrm{mg} / 100 \mathrm{~g}$ ) from the South-west of Nigeria. The daily 
requirements of copper are 1 to $2 \mathrm{mg}$. Copper $(\mathrm{Cu})$ participate in the synthesis of hemoglobin and collagen and is one of the components of several enzymes. The complex copper-enzyme contributes to the protection of the body against the free radicals (Thanonkaevw, 2006). Manganese contents of the edible parts of the studied shrimp are similar to those found by Adeyeye et al. (2008) in Nigeria pink shrimp, Paneus notialis $(0,6 \mathrm{mg} / 100 \mathrm{~g})$, but remain higher compared to those reported by Abdullah et al. (2009) in the pink shrimp Parapenaeus longirostris $(0.07 \mathrm{mg} / 100 \mathrm{~g})$ and in the red shrimp Parapenaeus martia $(0.01 \mathrm{mg} / 100 \mathrm{~g})$, and by Sriket et al. (2007) in Panaeus monodon $(0,1 \mathrm{mg} / 100 \mathrm{~g})$ and Litopanaeus vannamei $(0,048 \mathrm{mg} / 100 \mathrm{~g})$. Manganese is an activator of the pyruvate carboxylase and help for minerals fixation (Rodwell, 1994).

Results showed that $C$. turnerana with high contents in macro and microelements is a potential source of minerals which are vita for healthy growth, development of the body, functioning of the nervous system. It can be used in fighting against micronutrient deficiencies.

\subsection{Contents of Total Carotenoids, Vitamin E and Carotenoids Profile}

Total carotenoids contents for the edible parts were lower than those found by Sachindra et al. (2005) in Panaeus indicus $(10.4 \pm 0.92 \mu \mathrm{g} / \mathrm{g})$ and Metapaneus dobsonii $(11.1 \pm 1.61 \mu \mathrm{g} / \mathrm{g})$. However that of eggs approaches the values found by the same author on Penaeus monodon and Parapenaeopsis stylifera which were respectively of $17.4 \pm 5.99 \mu \mathrm{g} / \mathrm{g}$ and $16.0 \pm 2.21 \mu \mathrm{g} / \mathrm{g}$ and by Sachindra et al. (2006) in the shrimp Solonocera indica (15.9 \pm $2.1 \mu \mathrm{g} / \mathrm{g})$.

Vitamin E ( $\alpha$-tocopherol) contents obtained in this study were lower than those found by Chellaram et al. (2014) in Panaeus monodon $(56.71 \mu \mathrm{g} / \mathrm{g})$. This liposoluble vitamin is a powerful antioxydant whose activity is 10 times higher than that of vitamin A. It plays a major role in the neutralization of the free radicals, thus slowing down cellular ageing and preventing the oxidation of the polyunsaturated fatty acids (Kanazawa, 1985).

High levels of $\alpha$-carotene and $\beta$-carotene in C. turnerana showed that it is a good source of provitamins A for human. Niamnuy et al. (2008) reported that the major carotenoids in shrimps were the astaxanthin and its esters.Sachindra et al. (2005) reported that they can contribute to $63.5-92.2 \%$ of total carotenoids of shrimps, with small percentages of $\beta$ - carotene and of zeaxanthin. These results do not corroborate those found in the literature. Indeed, in $C$ turnerana, astaxanthin was not the major pigment. The $\beta$-carotene content is about 3 times that of $\alpha$-carotene in the males, females and eggs. It represents approximately 12.5 times the content of astaxanthin in the males, 32 times in the females and the eggs. Scarmo et al. (2010) report that the most widespread carotenoids in human plasma were: $\beta$-caroten, $\alpha$-caroten, the $\beta$-cryptoxanthin, lutein, lycopen and zeaxanthin. $C$. turnerana would be thus a significant source of carotene for the human.

\section{Conclusion}

This study showed that Callianassa turnerana has a poor water content and is rich in lipids, proteins and carbohydrates. The more abundant macroelements were sodium and phosphorus, and the main microelements were iron, zinc and copper. $C$. turnerana is also rich in vitamin $\mathrm{E}$ ( $\alpha$-tocopherol) and in total carotenoids. $\beta$-carotene was the main carotenoid in $C$. turnerana, followed by $\alpha$-carotene and astaxanthin. With high levels of macro and micronutrients, $C$. turnerana is a good source of many nutrients and essential elements.

\section{Recommendation}

C. turnerana can be recommended for human consumption to improve health and nutritional status of populations.

\section{Significant Statement}

This study is the first on chemical and biochemical of C. turnerana from Cameroonian water. The findings on its chemical composition will be helpful for further nutritional research on Cameroonian shrimp's species and marine foods.

\section{Conflict of Interest}

The authors declare no conflicts of interest related to this research work

\section{Acknowledgments}

The authors would like to acknowledge the Ministry of Higher Education of Cameroon for financing this work via "Appuie à la Modernisation de la Recherche". We are thankful to the Laboratory of Foods Sciences and Nutrition of University of Douala and to the Department of Physiology and pathophysiology of Nutrition of the University of Potsdam, Germany. 


\section{References}

Abdullah, O., Ayse, O., Mevlut, A., Gozde, G., \& Jelena M. (2009). A comparative study on proximate, mineral and fatty acid compositions of deep seawater rose shrimp (Parapenaeus longirostris, Lucas, 1846) and red shrimp (Plesionikamartia, A. Milne-Edwards, 1883). J. Anim. Vet. Adv., 8(1), 183-189.

Adeyeye, E. I., Adebiora, H. O., \& Awodola, O. J. (2008). Comparability and chemical composition and functional properties of shell and flesh of Penaeus notabilis. Pakistan J. Nutr., 7(6), 741-747. https://doi.org/10.3923/pjn.2008.741.747

Anderson, J. M., \&. Ingram, J. S. I. (1993). Tropical Soil Biology and Fertility: A Handbook of Methods, 2nd ed. CAB International, the Cambrian News, Aberstwyth, United Kingdom, 221p.

Association of Official Analytical Chemists (A.O.A.C). (1984). Official Methods of Analysis of the Association of the Official Analysis Chemists. Association of Official Analytical Chemists, 14th ed. A.O.A.C. International, Washington, DC.

Association of Official Analytical Chemists (A.O.A.C). (2005). Official methods of analysis, $16^{\text {th }}$ ed. Association of Official Analytical Chemists Washington USA Secs 930p.

Babu, A., Kesavan, K., Arnadurai, D., \& Rajagopal, S. (2010). Bursa spinosa A megastropod fit for human consumption. Advance Journal of Food Science and Technology, 2(1), 79-83.

Belitz, H. D., Crock, W., \& Schieberie P. (2009). Food Chemistry-Google Books Result-Technology and Engenering. pp 424-528. Retrieved from https://books.google.cm/books. htm last assessed on 09/01/2016

Bello, B. K. (2013). Effect of Processing Method on the proximate and Mineral Composition of Prawn (Penaeus notialis). J. Global Biosci., 2(2), 42- 46. https//doi.org/1011648/j.ijfsb.20160101.13

Bender, A. (1992). Meat and meat products in Human Nutrition in Developing countries. Food and Agriculture Organization. Food Nutrition Paper 53, Rome: FAO.

Benton, Jr J. J., \& Case, V. W. (1990). Sampling, handling and analyzing plant tissue samples, in: Westerman R.L. Soil Testing and Plant Analysis, third ed., SSSA Book Series No. 3, 1990.

Bernard, E., \& Yewande-Bolatio, A. (2016). Comparative study on the nutritional composition of the pink shrimp (Penaeus notialis) and tiger shrimp (Penaeus monodon) from Lagos lagoon,Southwest Nigeria. Cogent Food Agric. 2:120-189. https//doi.org/10.1080/23311932.2016.1201891

Bligh, E., \& Dyer, W. (1959). A rapid method for total lipid extraction and purification. Can J. of Biochem and Physiol., 37, 911- 917.https//doi.org/10.1139/059-099

Bu, S. Y., Kang, M. H., Kim E. J., \& Choi, M. K. (2012). Dietary intake ratios for calcium-tophosphorus and sodium-to-potassium are associated with serum lipid levels in healthy Korean adults, Prev. Nutr. Food Sci., 17(2), 93-100. https//doi: 103746/pnf.2012.17.2.093.

Buondonno, A., Rashad, A. A., \& Coppola, E. (1995). Comparing tests for soil fertility II. The hydrogen peroxide/sulfuric acid treatment as and alternatice to the copper/selenium catalyzed digestion process for routine determination of soil nitrogen-kjeldahl. Commun Soil Sci. Plant Anal., 6(9-10), 1607-1619. https://doi.org/10.1080/00103629509369394

Camara, F., Amaro, M. A., Barbera, R., \& Glemente, G. (2005). Bioaccessibility of minerals in school meals: between dialysis and solubility methods. Food Chem., 92, 481-489. http://dx.doi.org/10.1016/j.foodchem.2004.08.009

Chellaram, C., Prem Anand, T., Felicia Shanthini, C., Karthika, G., \& Vijayalakshmi C. (2014). Antioxidant properties of natural dietary common seafoods from Pulicat coast. J. chem. Pharm. Res. 6 (1): 611-613.

Dincer, M. T., \& Ayidin, I. (2014). Proximate composition and mineral and fatty acid profiles of male and female jinga shrimps (Metapenaeus affinis, H. Milne Edwards, 1887). Turk. J. Vet Anim. Sci., 38, 445-451. https://doi.org/10.3906/vet-1301-15

Ehigiator, F. A. R., \& Oterai, E. A. (2012). Chemical composition and amino acid profile of a caridean prawn (macrobrachium vollenhovenii) from Ovia River and tropical periwinkle (tympanotonus fuscatus) from Benin River, edo state, Nigeria. Inter J. Res. Rewies Appl. Sci., 11(1), 162-167.

Ekpenyong, E., Williams, I. O., \& Osakpa, U. U. (2013). Variation in the proximate, Energy and Mineral composition of different Body Parts of Macrobrachium macrobranchium (Prawn). J. Food Res., 2(2), 150-156. https://doi.org/10.5539/jfr.v2n2p150 
Food and Agricultural Organisation (FAO). (2016). La situation mondiale des pêches et de l'aquaculture; Contribuer à la sécurité alimentaire et à la nutrition de tous, Rome, 224 p.

Golub, E. E. (2011). Biomineralization and matrix vesicules. In: Biology and Pathology. Semin Immunopathol, 33, 409-417. https://doi.org/10.1007/s00281-010-0230-z

Gunalan, B., Nina Tabitha, S., Soundarapandian P., \& Anandé T. (2013). Nutritive value of cultured white leg shrimp Litopenaeus Vannamei., 5(7), 166-171.

Holthuis, L. B. (1991). Species catalogue, Marine Lobsters of the world. An annotated and illustrated catalogue of species of interest to fisheries known to data. FAO fisheries synopsis, 125(13), 292.

Kanazawa, A. (1985). Nutritional factors in fish reproduction. In reproduction and culture of Milkfish: Proceedings for a workshop held at the Tungkang Marine Laboratory, Lee, CS. and IC Liao (Eds). Oceanic Institute, Taïwan, pp 115-125.

Maniadis-Meimaroglou, S., \& Sinanoglou, V. J. (2012). Lipidomics: SeaFood, Marine Based Dietary Supplement, Fruit and Seed. Recent. Res. Dev. Org. Chem., 37/661 (2), 21-40.

Murphy, J. J., \& Riley, J. P. (1962). A modified single solution method for determination of phosphate in natural waters. Anal. Chim. Acta., 27, 31-36. https://doi.org/10.1016/S0003-2670(00)88444-5

Musaiger, A. O., \& D'Souza, R. (2008). The effects of different methods of cooking on proximate, mineral and heavy metal composition of fish and shrimps consumed in the Arabian Gulf. Arch. Latinoam. Nutr., 58(1), 103-109.

Niamnuy, C., Devahastin, S., Soponronnant, S., \& Vijaya Raghavan G.S. (2008). Kinetics of astaxantin degradation and color changes of dried shrimps during storage. J. Food Eng., 87(4), 591-600. https://doi.org/10.1016/j.jfoodeng.2008.01.013

Oksuz, A., Ozyilmaz, A., Aktas, M., Gercek Gozde \& Motte, J. (2009). A comparative study on proximate, Mineral and fatty acid composition of Deep Seawater Rose shrimp (Parapenaeus longirostris, Lucas 1846) and Red shrimps (Plesionita martia, A. Milne-Edwards, 1883). J. Anim. Vet. Adv., 8(1), 183-189.

Onyeike, E. N., Ayoologu, E. O., \& Ibegbulam, C. O. (2000). Evaluation of the nutritional value of some crude oil in polluted freshwater fishes. Global J. Pur. Appl. Sci., 6, 227-233.

Pauwels, J. M., Van Ranst, E., Verloo M., \& Mvondo, Z. A. (1992). Manuel de Laboratoire de Pédagogie-méthodes d'analyses des sols et des plantes; équipement et gestion des stocks des verreries et de produits chimiques. Publication Agricoles nr. 28, AGCD, Brussels, Belgique, 180p. Retrieved from http://hdl.handlenet/1854/LU-223183.

Perez, V., Ellen, T., \& Chang, V. (2014). Sodium-to-potassium ratio and blood pressure, hypertension, and related factors, Adv. Nutr., 5, 712-741. https//doi.org/ 10.3945/an.114.006783.

Ravichandran, S. G., Rameshkumar \& Rosario, P. A. (2009). Biochemical Composition of Shell and Flesh of the Indian White Shrimp (Penaeus indicus). A.E.J.S.R., 4(3), 191-194.

Rodwell, W. (1994). Essentials of Nutrition and Diet Therapy. Edition N 6. p146-148.

Sachindra, N., Bhaskar, N., \& Mahendrakar N. (2006). Recovery of carotenoids from shrimp waste in organic solvents. Waste Manage, 26, 1092-1098. https://doi.org/10.1016/j.wasman.2005.07.002.

Sachindra, N. M., Bhaskar, N., \& Mahendrakar, N.S. (2005). Carotenoids in different body components of Indian shrimp. J. Sci. Food Agric., 85, 167-172. https://doi.org/10.1002/jsfa.1977.

Scarmo, S., Cartmel, B., Lin, H., Leffell, D. J., Bhosale, P., Bernstein, P. S., \& Mayne, S. T. (2010). Significant correlations of dermal total carotenoids and dermal lycopene with their respective plasma levels in healthy adults. Arch. Biochem. Biophys, 504(1), 34-39. https://doi.org/10.1016/j.abb.2010.07.004.

Simpson, K. L., Tisou S. T. C., \& Chichester C. O. (1987). Biochemical methodology for assessment of carotenes. Monograph published by IVA C G. Washington. 45p.

Sriket, P., Soottawat, B., Wonnop, V., \& KongkarnKi, J. (2007). Comparative studies on chemical composition and thermal properties of black tiger shrimp (Penaeus monodon) and white shrimp (Penaeus vannamei) meats. Food Chemistry, 103, 1199-1207.

Sriket, S., Benjakul, P., Visessanguan W., \& Kijroongrojana, K. (2007). Comparative studies on chemical composition and thermal properties of black tiger shrimp (Penaeus monodon) and white shrimp (Penaeus vannamei) meats. Food Chem., 103, 1199-1207. https://doi.org/10.1016/j.foodchem.2006.10.039 
Thanonkaevw, A., Benjakul, S., \& Visessanguan, W. (2006). Chemecal composition and thermal property of Cuttefish (Sepia pharonis) muscle. J. Food Comp. Anal., 19(2-3), 127-133. https://doi.org/10.1016/j.jfca.2005.04.008

Varadharajan, D., \& Soundarapandian, P. (2014). Proximate composition and mineral contents of freshwater crab Spiralothelphusa hydrodroma (Herbst, 1794) from Parangipettai, South East Coast of India. J. Aqua. Res. Dev., 5(2), 1-6.

Yanar, Y., \& Celik, M. (2006). Seasonal amino acid profiles and mineral content of green tiger shrimp (Penaus semisulcatus, De Haan, 1844) and speckled shrimp (Metapenaus monoceros, Fabricus 1789) from the Eastern Mediterranean sea. Food Chem., 94, 33-36. https://doi.org/10.1016/j.foodchem.2004.09.049

\section{Copyrights}

Copyright for this article is retained by the author(s), with first publication rights granted to the journal.

This is an open-access article distributed under the terms and conditions of the Creative Commons Attribution license (http://creativecommons.org/licenses/by/4.0/). 